\title{
Strategi Penyajian Berita Brilio.net (Studi Kasus: Media Online Menjangkau Generasi Milenial)
}

\author{
Alvianne Suseno, Farid Rusdi \\ alvianne.915150139@stu.untar.ac.id,farid@fikom.untar.ac.id \\ Fakultas Ilmu Komunikasi Universitas Tarumanagara
}

\begin{abstract}
A case study of strategies in presenting news carried out by online media namely Brilio.net to reach the millennial generation as the target audience. This study uses a case study approach with qualitative methodology and Mike Ward's theoretical concept of the presentation of news and Lyons's theory of millennial generations in online news reading. The results of the study and conclusions from this study are that Brilio.net does the writing and presentation of news based on millennial generation characteristics as much as possible and makes the millennial generation read the Brilio.net news through their gadgets due to the presentation of news in electronic format and the number of multimedia or photos and videos as other forms of presenting news. Brilio.net also carried out a strategy by conducting negotiations on what news will be presented to the millennial generation every day and making a strategy to make young journalists as journalists from Brilio.net to reach the millennial generation itself.
\end{abstract}

Keywords: Online Media, New Media, Millennial Generation, News Presentation

\begin{abstract}
Abstrak
Penelitian ini mengangkat strategi menyajikan berita yang dilakukan oleh media online yaitu Brilio.net guna menjangkau generasi milenial sebagai audiens sasaran. Studi ini menggunakan pendekatan studi kasus dengan metodologi kualitatif dan konsep teori oleh Mike Ward mengenai penyajian berita dan teori Lyons mengenai generasi milenial dalam membaca berita online. Hasil penelitian dan simpulan dari penelitian ini adalah Brilio.net melakukan penulisan dan penyajian berita berdasarkan karakteristik generasi milenial semaksimal mungkin dan membuat generasi milenial betah membaca berita Brilio.net melalui gadget-nya. Hal ini dikarenakan penyajian berita dengan format listikal dan banyaknya multimedia atau foto dan video sebagai bentuk lain dalam menyajikan berita. Brilio.net juga melakukan strategi dengan melakukan perundingan mengenai berita apa yang akan disajikan kepada generasi milenial setiap hari, serta melakukan strategi menjadikan jurnalis muda sebagai jurnalis dari Brilio.net untuk menjangkau generasi milenial itu sendiri.
\end{abstract}

Kata Kunci : Media Online, New Media, Generasi Milenial, Penyajian Berita

\section{Pendahuluan}

Manusia membutuhkan informasi sebagai pemenuh kebutuhan kognitifnya (Tan dalam Yusup, 2009:338). Dalam kehidupan, manusia membutuhkan informasi sebagai bagian dari pemenuhan kebutuhan kognitif. Saat ini, dengan seiring berkembangnya teknologi, media online atau internet Atau new media adalah salah satu media yang sangat diminati dalam mencari berita dan informasi, khususnya bagi generasi milenial. 
Seiring berjalannya waktu, media online berkembang dan melihat bahwa generasi milenial memiliki ketertarikan dan tingkah laku yang berbeda dengan generasi lainnya dalam hal membaca dan mencari suatu informasi. Berdasarkan artikel inews.id pada Rabu, 14 Februari 2018, Bappenas menyebutkan bahwa jumlah milenial di Indonesia mencapai 90 juta orang. Angka ini adalah jumlah yang besar. Hal inilah yang menjadi asal mula dari banyak bermunculan media online yang menargetkan generasi milenial sebagai target khalayak. Dengan kata lain, media online tersebut memang khusus membuat konten dan tampilan yang disukai oleh generasi ini.

Generasi milenial adalah generasi yang sangat aktif saat ini. Generasi milenial membutuhkan informasi untuk memenuhi kebutuhan kognitifnya tersebut. Namun dalam mencari informasi, generasi ini memiliki kesukaan tersendiri. Hal ini terjadi karena adanya karakteristik berbeda yang menonjol oleh generasi milenial dibandingkan generasi lain.

Generasi milenial adalah generasi yang lahir pada rentang tahun 1990-2000-an. Artinya, generasi ini lahir di saat teknologi sudah ada. Oleh karena itu, generasi ini menganggap teknologi adalah tren atau gaya hidup yang melekat dalam keseharian mereka. Hal ini sangat berpengaruh dengan media berita. Media konvensional seperti televisi, koran ataupun radio sudah bukan menjadi pilihan dari generasi milenial untuk mendapatkan informasi. Generasi ini memilih media online sebagai cara untuk mendapatkan informasi ini. Berdasarkan kutipan dari Marketeers survey.com, MarkPlus Insight bertajuk Youth Monitoring 2015 di 18 kota di Indonesia mengatakan, ketika membutuhkan informasi yang cepat, internet dan media online menjadi solusi yang dicari oleh anak muda. Internet merupakan tren yang lekat dengan generasi milenial. Media online juga dikenal sebagai new media. Menurut Asep Syamsul M. Romli (2012:30), media baru atau new media adalah media massa yang tersaji secara online di situs website yang berbasis internet.

Walaupun dijadikan pilihan nomor satu oleh generasi milenial dalam memilih media massa untuk mendapatkan informasi, tidak menjadikan masing-masing perusahaan media online mencari cara dan strategi tersendiri untuk mendapatkan viewers sebanyak-banyaknya. Salah satu media online yang menjadikan generasi milenial sebagai target audiens nya adalah Brilio.net. Penyajian yang berbeda menjadi ketertarikan sendiri bagi generasi milenial untuk menjadikan Brilio.net bacaan berita dan informasi sehari-hari.

\section{Metode Penelitian}

Penelitian ini bertujuan untuk memahami secara dalam mengenai strategi yang dilakukan oleh Brilio.net dalam menyajikan berita kepada generasi milenial. Untuk itu penelitian ini menggunakan penelitian deskriptif-kualitatif. Menurut Bogdan dan Taylor dalam Moleong (2011: 4), penelitian kualitatif adalah penelitian yang menghasilkan data deskriptif berupa kata-kata tertulis atau lisan dari orang-orang dan perilaku yang dapat diamati.

Menurut Sugiyono (2015:11), penelitian kualitatif merupakan penelitian yang berlandaskan pada filsafat positivisme, digunakan untuk meneliti pada kondisi obyek yang alamiah, (sebagai lawannya adalah eksperimen) dimana peneliti adalah sebagai instrumen kunci, pengambilan sampel sumber data dilakukan secara purposif dan snowball, teknik pengumpulan dengan triangulasi (gabungan), analisis data bersifat 
induktif/kualitatif, dan hasil penelitian kualitatif lebih menekan makna dari pada generalisasi.

Selain itu, penulis melakukan penelitian dengan metode studi kasus. Menurut Wilgato (2010), studi kasus adalah metode yang bertujuan untuk mempelajari dan menyelidiki suatu kejadian atau fenomena mengenai individu atau kelompok. Walgito juga menambahkan bahwa dibutuhkan banyak informasi dan integrasi data guna mendalami penelitian yang dilakukan dengan metode studi kasus.

Ada pula pendapat dari Rahardjo \& Gudnanto (2011:250) bahwa studi kasus adalah suatu metode untuk memahami individu yang dilakukan secara integrative dan komprehensif agar diperoleh pemahaman yang mendalam tentang individu tersebut beserta masalah yang dihadapinya dengan tujuan masalahnya dapat terselesaikan dan memperoleh perkembangan yang baik.

Dengan menggunakan studi kasus dalam penelitian ini, penulis ingin menggali dan mengetahui secara mendalam bagaimana strategi atau langkah-langkah yang digunakan Brilio.net sebagai sebuah media online untuk dapat menjangkau generasi milenial dan mengapa generasi milenial lebih tertarik membaca media sejenis Brilio.net dibandingkan media konvensional. Karena menggunakan penelitian deskriptif-kualitatif dengan metode studi kasus, wawancara mendalam dan observasi langsung ke lapangan dirasa sangat tepat untuk melakukan penelitian ini.

Dalam penelitian ini yang menjadi subjek penelitian adalah Brilio.net. Pemilihan subjek ini dirasa cocok karena eksistensinya. Dikutip dari www.swa.co.id di tahun 2017, Brilio.net mampu meraih 1,2 miliar content view. Objek dari penelitian ini adalah penyajian berita dari Brilio.net itu sendiri. Perusahaan Brilio.net telah setuju untuk dijadikan subjek dan objek penelitian dan profile perusahaan ditulis secara jelas dan rinci dalam penelitian ini.

\section{Hasil Temuan dan Diskusi}

Dalam penelitian ini, penulis melakukan wawancara dan observasi mendalam untuk memperoleh data kualitatif yang diperlukan dan sesuai dengan penelitian. Peneleti melakukan wawancara langsung di Kantor Redaksi Brilio.net di Yogyakarta pada bulan November 2018 yang sebelumnya telah disetujui oleh Brilio.net Jakarta. Wawancara dan observasi langsung yang dilakukan penulis dilakukan pada November 2018.

Hasil dari wawancara dan observasi yang dilakukan penulis adalah Brilio.net mengupayakan menyajikan berita sesuai dengan karakteristik generasi milenial yang praktis, cepat, gadget friendly dan pembahasan yang ringan meskipun terhadap isuisu yang berat sekalipun.

Dalam wawancara yang dilakukan penulis dengan Titis Widyatmoko dan selaku Pemimpin Redaksi Brilio.net, informan mengatakan bahwa generasi milenial adalah generasi yang memiliki karakteristik yang berbeda. Mulai dari habit, gaya hidup, kesenangan bahkan bagaimana mereka mencari berita. Oleh karena itu, Brilio.net juga harus menjadi media online yang berbeda untuk mendapatkan perhatian dari generasi ini.

"Kami sadar bahwa generasi milenial memiliki habit yang berbeda, mereka mendapatkan berita bukan dari TV, bukan dari radio, bukan dari koran, tapi melalui smartphone mereka. Layar smartphone itu kan kecil, tidak sebesar TV, koran atau komputer. Jika menggunakan teks yang 
panjang, mereka akan cenderung pergi setelah membaca beberapa kalimat pertama, sehingga kami perlu meminimalkan tulisan, mereka juga menyukai konten yang memiliki banyak gambar, video dan infografis, maka kami membuat konten dalam bentuk listikal. Dengan listikal, teks lebih sedikit dan dapat input banyak multimedia"(Wawancara dengan Titis Widyatmoko di kantor redaksi Brilio.net Yogyakarta pada November 2018).

Jika membicarakan generasi milenial, yang sangat disorot adalah karakteristiknya. Generasi ini adalah generasi yang sangat bergantung terhadap teknologi. Bahkan teknologi dianggap sebagai gaya hidup. Mereka serba instant namun optimis dan memiliki keingintahuan yang tinggi. Hal inilah yang menjadikan media online sangat digandrungi oleh generasi ini.

Sebagai sebuah media yang menargetkan audiens generasi milenial, menjadi media online yang ada pada umumnya saja akan sangat sulit bagi Brilio.net karena banyak pesaing dari media online lainnya.

"Kalau secara umur kan mereka di umur 20-30, mereka lahir sudah ada di era teknologi, ini sangat mempengaruhi gaya mereka sehari-hari. Jika disangkutkan dengan Brilio, jelas Brilio menyikapi dengan menyajikan berita dengan gaya mereka. Terkhusus adalah mereka itu adalah generasi yang praktis dan ini diaplikasikan dengan gaya penulisan Brilio." (Wawancara dengan Fefy Dwi Haryanto selaku Assignment Editor pada bulan November di kantor redaksi Brilio.net di Yogyakarta."

Pertanyaan lainnya yakni mengapa Brilio.net perlu menjadi media online yang berbeda? karena generasi milenial tidak menerima suatu media online hanya dari segi membaca dan mencari berita melalui media online saja. Tetapi juga format dan konten sajian yang harus senafas sehingga mudah diterima oleh mereka.

"Generasi milenial sangat aktif dan memiliki kecenderungan ingin menonjol dan diakui, sangat peduli dengan lingkungan dan memiliki aksi sosial yang tinggi. Sifat ini juga mempengaruhi mereka dalam mencari berita, konten sejenis ini sangat mudah diterima oleh generasi milenial karena dapat dikatakan 'senafas"'(Wawancara dengan Titis Widyatmoko di Kantor Redaksi Brilio.net Yogyakarta pada November 2018).

Salah satu teori yang sangat terkenal dalam media online adalah teori Mike Ward. Teori Mike Ward menjelaskan bahwa ada lima karakteristik dari media online:

\section{Immediacy}

Immediacy yang dimaksud disini adalah kecepatan dan kesegaran berita dari penyajian berita. Seperti yang diketahui, generasi milenial memiliki mobilitas yang tinggi dan cepat bosan. Brilio.net harus menyeimbangi karakter ini dengan penyajian beritanya. Berita yang cepat dan segar akan membuat generasi ini betah membaca Brilio.net.

"Visi kita adalah menjadi rujukan bacaan online untuk generasi muda. Sehingga kami juga ingin meng-entertain pembaca kita. Tidak ketinggalan 
kami ingin meng-educate. Agar visi ini tercapai, kami harus terus ter-update dalam menyajikan berita." (Wawancara dengan Titis Widyatmoko di kantor redaksi Brilio.net Yogyakarta pada November 2018.)

Kesegaran dan kecepatan berita ini dikelola oleh Brilio.net dengan cara melakukan rapat redaksi tiap hari dan rapat besar setiap minggunya. Dengan begitu Brilio.net dapat memberikan berita yang cepat dan segar kepada pembaca milenial. Walapun cepat dan segar tapi berita yang disajikan juga disiapkan secara matang.

\section{Multiple Pagination}

Generasi milenial adalah generasi yang sangat kritis dan serba ingin tahu terhadap suatu topik yang sedang hangat. Mereka akan menggali dari satu bacaan ke bacaan lain untuk membuktikan bahwa isu yang beredar adalah benar dan mereka ingin tahu lebih jauh tentang berita yang ada.

Generasi ini juga merupakan generasi yang selalu menggunakan gadget, sehingga mencari berita secara terus menerus bukanlah hal yang sulit. Maka dari itu multiple pagination diperlukan dalam suatu website dari media online sehingga mempermudah mereka dalam mencari berita di satu website saja tanpa harus berpindah website.

Dalam website Brilio.net, multiple pagination yang dilakukan oleh Brilio.net adalah dengan adanya fitur Recommend by Editor di bawah halaman suatu berita atau bacaan. Dengan begitu, pembaca dapat langsung mendapatkan berita yang berkaitan dengan berita sebelumnya yang telah dibaca.

\section{Multimedia}

Menurut kutipan dari CNN Indonesia dalam artikel berjudul "Milenial dan Karakteristiknya", salah satu poin menyebutkan bahwa generasi milenial tidak menyukai membaca secara konvensional artinya, generasi ini tidak menyukai membaca dengan cara lama. Cara lama yang dimaksud adalah membaca melalui koran, buku fisik, majalah dan sebagainya.

Selain ini, dengan mencetak suatu bacaan, ada biaya tambahan yaitu biaya cetak. Dengan adanya biaya cetak, penyedia bacaan akan memasukan lebih banyak tulisan daripada gambar agar bacaan tersebut mengandung banyak informasi. Kasus ini jelas berbeda dengan media online yang tidak membutuhkan melakukan suatu hal yang dinamakan mencetak.

Media online dapat melakukan multiple pagination tanpa biaya tambahan apapun. Hal ini karena yang dibutuhkan adalah internet sebagai syarat dari new media. Dengan demikian, memasukan multimedia sebagai wujud penyajian beritanya adalah nilai tambah bagi media ini.

Milenial juga menyukai hal-hal praktis dan beriringan dengan gadget. Hal inilah yang menjadikan suatu media online Brilio.net menaruh banyak multimedia daalam penyajian beritanya.

"Kami sadar bahwa generasi milenial memiliki habit yang berbeda, mereka mendapatkan berita bukan dari TV, bukan dari radio, bukan dari koran, tapi melalui smartphone mereka. Layar smartphone itu kan kecil, tidak sebesar $T V$, koran atau komputer bahkan.Jika menggunakan teks yang panjang, mereka akan cenderung pergi setelah membaca beberapa kalimat pertama, sehingga kami perlu meminimalkan tulisan, mereka juga menyukai konten 
yang memiliki banyak gambar, video dan infografis, maka kami membuat konten dalam bentuk listikal. Dengan listikal, teks lebih sedikit dan dapat input banyak multimedia" (Wawancara dengan Titis Widyatmoko selaku Pemimpin Redaksi Brilio.net di kantor redaksi Brilio.net Yogyakarta pada November 2018).

Selain itu, menurut narasumber lainnya yaitu Nanang Fahrudin selaku coordinator tim video Brilio.net, mengatakan bahwa mereka melihat bahwa kebutuhan akan informasi umumnya yang terjadi pada semua orang bukan hanya berbentuk teks atau tulisan, tapi juga gambar dan video. Hal ini dirasa benar adanya oleh penulis. Jika hanya teks, cepat atau lambat media online akan bersaing dengan televisi. Jika bukan televisi, tetap saja media lain yang menggunakan banyak multimedia seperti foto dan video akan menjadi pilihan genenerasi milenial.

"Kebutuhan akan informasi anak muda, tidak hanya berbentuk teks dan anak muda lebih menyukai berita yang berbentuk visual, sehingga video menjadi second line atau member warna di website Brilio.net sendiri. Selain itu, mempermudah audiens untuk menikmati berita dalam sajian lain dan sekarang kita harus masuk ke instagram dan youtube agar mengikuti keinginan milenial."(Wawancara dengan Nanang Fahrudin selaku koordinator tim video di kantor redaksi Brilio.net Yogyakarta pada November 2018).

\section{Archieving}

Dalam karakteristik ini, Brilio.net melakukan pendekatan terhadap pembacanya dengan cara mempermudah para milenial mengakses suatu topik atau tema bacaan dengan melakukan pengelompokan terhadap genre bacaan dan kata kunci pencaharian.

Seperti yang sudah dibahas sebelumnya, milenial memiliki karakteristik mobilitas yang tinggi namun menginginkan semua hal yang dilakukan ringkas. Generasi milenial juga kritis terhadap suatu topik dan isu khususnya yang berhubungan dengan lingkungan hidup, sehingga mencari informasi sebanyakbanyaknya mengenai suatu isu adalah hal yang wajar dilakukan oleh generasi ini.

Dalam berupaya mempermudah generasi milenial dalam mencari berita yang memiliki kesamaan topik dan tema dan genre, Brilio.net membagi-bagikan beritanya dalam bentuk "kolom", dalam redaksi Brilio.net disebut "desk". Fitur ini ditemukan dalam kolom "creator".

\section{Relation with Reader}

Menurut penelitian berdasarkan Pew Research Center di tahun 2010 dengan judul "A Potrait of Generation Next", disampaikan bahwa milenial lebih mempercayai User Generated Content daripada informasi searah. Artinya, generasi ini memiliki kecenderungan untuk kritis dan berdiskusi. Milenial menyukai keikutsertaannya dalam suatu isu yang ada di lingkungannya, sehingga mereka cenderung mencari berita yang tidak hanyika dibuat untuk searah tapi mereka juga bisa membagikan pendapat mereka.

Jika ditinjau dari website Brilio.net, Brilio.net menaruh beberapa fitur untuk memperkuat relation with reader, antara lain adalah menaruh kolom komentar dan pembaca dapat memberikan reaksinya terhadap bacaan tersebut. 
Dalam penelitian oleh Pew Reaserch Center di tahun 2010 ini juga dikatakan bahwa generasi milenial adalah generasi yang wajib memiliki media sosial. Salah satu ciri-ciri generasi milenial adalah pengguna media sosial online yang fanatik. Hal ini sangat diikuti oleh Brilio.net. Seperti yang dikatakan informan Nanang, Brilio.net juga meng-upload berita dan konten-konten lainnya ke media sosial, seperti Instagram dan Youtube.

Jika dikaitkan dengan sifat mereka yang proaktif dalam setiap isu yang ada di lingkungan hidup mereka dan mereka gemar mendiskusikan suatu isu lebih dalam terhadap sesama pembaca. Maka generasi ini pasti akan melakukan sharing melalui media sosial lainnya kepada teman-teman di lingkungannya. Ditinjau dari website, Brilio.net juga memberikan kemudahan kepada pembaca melakukan diskusi dan membagikan suatu bacaan kepada orang lain di platform sosial media lainnya dengan cara menaruh fitur tersebut di atas kolom berita.

Selain melakukan strategi melalui melihat dari sudut pandang karakteristik generasi milenial itu sendiri, penulis juga meninjau dari segi strategi media itu sendiri. Strategi atau perencanaan media ditinjau dari empat kegiatan, namun yang penulis ingin fokuskan adalah strategi dalam memilih target audiens dengan tepat sesuai dengan visi misi suatu perusahaan media adalah hal yang krusial. Jika salah menetapkan audiens untuk suatu media, dapat mengakibatkan suatu media kehilangan exposure dari media itu sendiri.

Brilio sangat jelas telah melakukan pemilihan audiens dengan sangat tepat, dengan meninjau kebutuhan masyarakat dan gaya hidup, demografis dan geografis. Brilio.net sejak awal telah menentukan target sasarannya yaitu generasi milenial. Setelah memilih audiens, agar dapat menjangkau target, jurnalis yang terdapat di suatu media haruslah memahami dan mengenal betul audiensnya.

Dalam mengupayakan hal ini, Brilio.net juga cenderung mempekerjakan jurnalis dalam rentang umur yang tergolong milenial. Menurut penulis, strategi ini sangat cermat. Karena dengan diiringi jurnalis dengan latar belakang yang sama dengan audiens, penyajian berita dan konten oleh Brilio.net juga akan sangat terasa dekat dengan audiens itu sendiri.

"Karena memiliki target pembaca kaum muda atau milenial, agar dapat mencapai target, kami mengupayakan bahwa reporter-reporter kami juga berada di bentang generasi tersebut. Dengan begitu, kami bisa tahu apa yang dibutuhkan dan disukai milenial secara update melalui internal yaitu dimulai dari diri sendiri. Saat ini reporter kami kebanyakan diumur 25-an"

\section{Ucapan Terima Kasih}

Ucapan terimakasih diberikan kepada Fakultas Ilmu Komunikasi Universitas Tarumanagara, pembimbing Farid Rusdi, S.S., M.Si dan juga kepada narasumber yang telah membantu sebagai narasumber, serta kepada semua pihak yang turut mendukung dan membantu penelitian ini. Tanpa bantuan dari semua orang yang terlibat dalam penelitian ini, penelitian ini tidak dapat terwujud. Penulis sadar bahwa penelitian ini masih memiliki banyak kekurangan. Namun penulis berharap penelitian ini dapat berguna untuk semua orang yang membutuhkannya baik untuk akademis ataupun praktik. 


\section{Daftar Pustaka}

Asep Syamsul M. Romli. (2012). Jurnalistik Online: Panduan Mengelola Media Online. Bandung: Nuansa Cendikia

Diahnisa, Tiffany. (2017). Strategi Brilio.net Raih Kenaikan Jumlah Pembaca Hingga 139\%. https://swa.co.id/swa/trends/strategi-brilio-net-raih-kenaikanjumlah-pembaca hingga-139

Moleong, L.J. (2011). Metodelogi Penelitian Kualitatif Edisi Revisi. Bandung: PT. Remaja Rosdakarya

Pawit, M. Yusup. (2009). Ilmu Informasi, Komunikasi dan Kepustakaan . Ed. 1. Jakarta: Bumi Aksara

Rahardjo, Susilo dan Gudnanto. (2011). Pemahaman Individu Teknik Non Tes. Kudus: Nora Media Enterprise

Sembiring, Lidya Julita. (2018). Bappenas: Jumlah Milenial di Indonesia Capai 90 Juta Orang. https://www.inews.id/finance/read/ 6521/bappenas-jumlahmilenial-di-indonesia-capai-90-juta-orang

Sugiyono. (2011). Metode Penelitian Kualitatif, Kualitatif dan R\&D. Bandung: Alfabeta

Walgito, Bimo. (2010). Bimbingan dan Konseling (Studi \& Kasus). Yogyakarta: Andi

Ward, Mike. (2002). Journalism Online. Great Britain: Focal Press 